\title{
New species and records of Trichoptera collected by Mr. A. G. Duff. More phenomics and less genomics!
}

\author{
J. OLÁH
}

János Oláh, Tarján u. 28, H-4032 Debrecen, Hungary.E-mail: profolah@gmail.com

\begin{abstract}
Seven species are recorded and ten new species are described from Oriental, Afrotropical and Neotropical Fauna Regions: Abacaria dufforum sp. nov., Cyrnellus kesken sp. nov., C. kozepes sp. nov., Orthotrichia palama sp. nov., Marilia annae sp. nov., Phylloicus kinovos sp. nov., Atanatolica homora sp. nov., Oecetis fura sp. nov., O. siska sp. nov., Contulma duffi sp. nov. Based on theoretical outline of how to delineate young incipient sibling species with more phenomics and less genomics, the new species complex of Oecetis amazonica is erected as well as an instantiated failure of neutral DNA markers are presented on Allogamus auricollis and A. alpinus siblings.
\end{abstract}

Keywords. Trichoptera, phenomics, genomics, species delimination, adaptive traits

\section{INTRODUCTION}

A ndrew G. Duff, the author of Beetles of Britain and Ireland, the first comprehensive account of the beetles of the British Isles since Joy's "A Practical Handbook of British Beetles" published in 1932, is a devoted birdwatcher with a keen interest to see and enjoy biodiversity of birds in various biomes of faunal regions. During his travelling and birdwatching together with his wife he has collected caddisfly adults. This small but interesting Trichoptera collection composed of mostly undescribed species is elaborated and described here. Some theoretical aspects of the sibling species concept realised by fine structure analysis is briefly outlined here to support the Oecetis amazonica new species complex recognised here.

\section{MATERIAL AND METHODS}

The last abdominal segments of specimens are cleared for finer structure analysis and stored in small vials together with the rest of the animals in alcohol. All types and specimens are deposited in Oláh Private Collection under protection of Hungarian Natural History Museum.

\section{THEORETICAL PART}

\section{More phenomics and less genomics}

Specimens collected by Mr Duff from different localities in Argentina and determined here as Oecetis amazonica may represent two undescribed incipient sibling species (see taxonomic part). We have compared them with all the published drawings: (1) drawing of lectotype from Manaos (Flint 1967), (2) drawings of specimens from Bolivia (Martin et al. 2011) (3) drawings of specimens from north-eastern Brazil (Quinteiro \& Calor 2015). The lateral profiles of the phallic organ on the drawings as well as on our specimens suggest that Oecetis amazonica (Banks, 1924) is not a single species. It represents a species complex probably with several contemporary diverged, but undiscovered young species. In the six examined specimens the disposition of the forewing crossvein in the anastomosis, the shape of cerci and segment $\mathrm{X}$ is apparently unstable, varying. However the lateral profile of the gonopods and especially the ventrum of the phallic organ are stable. Unfortunately in the listed drawings the resolution and drawing principles and styles of the phallic organ are not stan-

urn: lsid:zoobank.org:pub:39A3D56E-19DB-44CC-AAFB-E967AD6E872F

HU ISSN 2063-1588 (online), HU ISSN 0237-5419 (print) http://dx.doi.org/10.18348/opzool.2016.2.155 
dardized like to the drawings of Blahnik \& Holzenthal (2014). Moreover, the basic architecture of the bilobed phallobase with the exact lateral position of the foramen for ductus ejaculatoricus is not indicated in all of the published drawings. The exact lateral profile of the phallobase ventrum needs to be clearly indicated on the drawings starting from the ventral lip of the foramen and covering the entire ventral tip of the phallobase up to the fuse of the left and right lobes apicad. This part of the phallic organ seems more sclerotized and more stable, and not liable to be influenced neither by natural copulatory movements, accidents or injuries nor by artefacts occurring during storage and preparation. The shape of the phallobase was found most stable and applicable to delineate young species also in the Oecetis avara group (Blahnik \& Holzenthal, 2014).

Much more information on phenomics is available and readable from the fine structure analysis of the phallic organ also in the new species complex of Oecetis amazonica: (1) lateral ratio of length/height dimension (2) dorsal ratio of phallus to genital capsule; (3) dorsal ratio of left and right lobe, (4) position and displacement of foramen; (4) asymmetry of foramen disposition; (5) development of foramen ring or phallic apodeme; (6) dorsal profile asymmetry of left and right lobes; (7) lateral profile asymmetry of the left and right lobes; (8) entire lateral profile of the ventrum; (9) lateral shape of the downward projecting ventral apex; (10) apical shape of ventral apex; (11) ratio of ventral apex length to height of the phallus; (12) position of paramere base; (13) discernibility and shape of paramere shape; (14) curvature of paramere spine; (15) length of paramere spine; (16) thickness of paramere, (17) head shape of paramere spine.

Compared to the simple structure of the phallic organ in the Oecetis (Oecetis) subgenus, even much more taxonomic information is encoded in the very complex sclerotized fine structure of the vaginal sclerite complex, not utilised yet in species delineation and delimitation. This structure coevolves with the phallic organ in the various sexual selection processes. Its phenomics is an "easy to explore" empirical reality waiting to be realized in the taxonomy of contemporary divergences compared to the virtual availability of combined effects of genomics, epigenomics, transcriptomics, primary and structural proteomics.

This combined reality with formidable complexity is almost undetectable for the initial splits of speciation traits in routine practice of the taxonomy to discover incipient siblings of biodiversity. Barcoding or trials to replace taxonomy with primitive oversimplified models of the expensive, fashionable, but inherently blind neutral markers of various DNA sequences proved to be a highly financed fatal reductionism.

In present day taxonomy, but not in molecular genetics, this is a deleterious ontological, theory and methodological reductionism: a philosophical position that connects phenomena or theories by unjustified reduction of complex to simple, of biological phenomena to chemistry, assuming that complex is nothing but the sum of its parts or maximum may have features that none of the parts have. This conceptual or epistemological reductionism (1) replaces entities of reality with other entities presuming non-existing relationship between them; (2) operates higher level reducebility to lower levels with different properties; (3) and even works with certain perspective of causality. These epiphenomena, like Huxley's steam whistle or the neutral markers in taxonomy, exert no real causal agency on more fundamental phenomena of speciation trait. The taxonomic waste of epiphenomenalism in DNA marker industry however may have important by-product value like association of sex and life stages in fingerprint industry of applied taxonomy. Any historically selected neutral markers so vehemently introduced and fashionably applied in taxonomy (1) has no direct relation to traits acting in contemporary speciation processes; (2) horribly replaces speciation traits with neutral markers; (3) reduce speciation process to alien DNA sequence divergences; (4) compute and model non-existing perspectives of causalities. 


\section{Instantiated failure of neutral markers}

This impasse of molecular genetic to dominate taxonomy has created more problems than solved in the science of biodiversity (Oláh et al. 2015). A recently published cladogram of Allogamus auricollis populations from Barcode of Life Database demonstrates the limits of these blind sequences and the taxonomic blindness of their advocates in biodiversity (Malicky 2016).

This dark coloured species is a widely distributed and an abundant autumnal caddisfy in the European mountains demarcated by Spain, England, Ukraine, and Albania. In his monograph Schmid (1951) examined only a limited number of populations and distinguished two geographic races based on paramere spine pattern and sclerite shape of the aedeagus: (1) race of the Jura Mts. and Silesia, and (2) race of the Alps Mts. In his European Trichoptera atlas Malicky (2004) has routinely applied an excuse theory and practice: the variability of widely distributed species.

Applying the sexual selection-driven, therefore adaptive, non-neutral traits of the phallic organ as well as the phylogenetic species concept of incipient siblings we have examined many populations of $A$. auricollis from the entire distributional area and distinguished two incipient sibling species (Oláh et al. 2014). (1) The ancestral Allogamus auricollis (Pictet, 1834) species widely distributed on the entire distributional area demarcated above, but populating also significant territories in the Alps. (2) We have separated a new species Allogamus alpensis Oláh, Lodovici \& Valle, 2014 distributed mostly in western parts of the Alps. It was a great experience to realise again how stable are the speciation traits also in this couple of incipient siblings evolved in contemporary sexually adaptive divergences through integration of reproductive barriers and by reinforcement in contact zones. The ancestral species $A$. auricollis has very stable adaptive speciation traits on the huge distributional area from Spain and England to Ukraine and Albania. This species is not much variable.

\section{TAXONOMY}

\section{Family Xiphocentronidae}

\section{Abaria dufforum sp. nov.}

(Figures 1-4)

Diagnosis. According to the unique shape of excision on the apical margin of tergum VIII, this species is close to A. dusyanta Schmid, 1982 described from Madras, India. The gonopod ventral profile is also similar. However the setal neoformations present on femur of the foreleg and on the $5^{\text {th }}$ to $8^{\text {th }}$ antennal segments lacking in the new species as well as the ventral dentate profile of the gonopods is also different.

Description. Male (in alcohol). Small pale brown animal. Head dorsum highly bulging, domed and pale brown; pronotal and mesonotal sclerites only slightly darker, sutures darker. Antennae without neoformation of long setal fringes. Maxillary palp formula is I- II-III-IV-V, gradually increasing from segment I to segment IV, segment $\mathrm{V}$ shorter than segment I-II-III-IV together. A pair of enlarged frontal lateral compact setose warts dominates on the face, occupying almost the entire surface of frontal area and touching medially on their posterior or dorsal section and untouched and diverting laterad on their anterior or ventral area. On head dorsum four pairs of compact setose warts are present: (1) postgenal compact setose warts, (2) occipital compact setose warts, (3) vertexal ocellar compact setose warts, (4) vertexal lateroantennal compacts setose warts are present; frontal interantennal compact setose wart not discernible. There is no any compact setal wart present nor on the cervix neither on the cervical sclerite. Proepisternal and precoxal setal warts present and packed with long and strong setae. Spur formula is 043; anterior spurs much shorter; apical spur on hindleg not modified. Forelegs without neoformations of long and black setal fringes on mesal surfaces of both femurs and tibiae. Forewing length $3 \mathrm{~mm}$. 


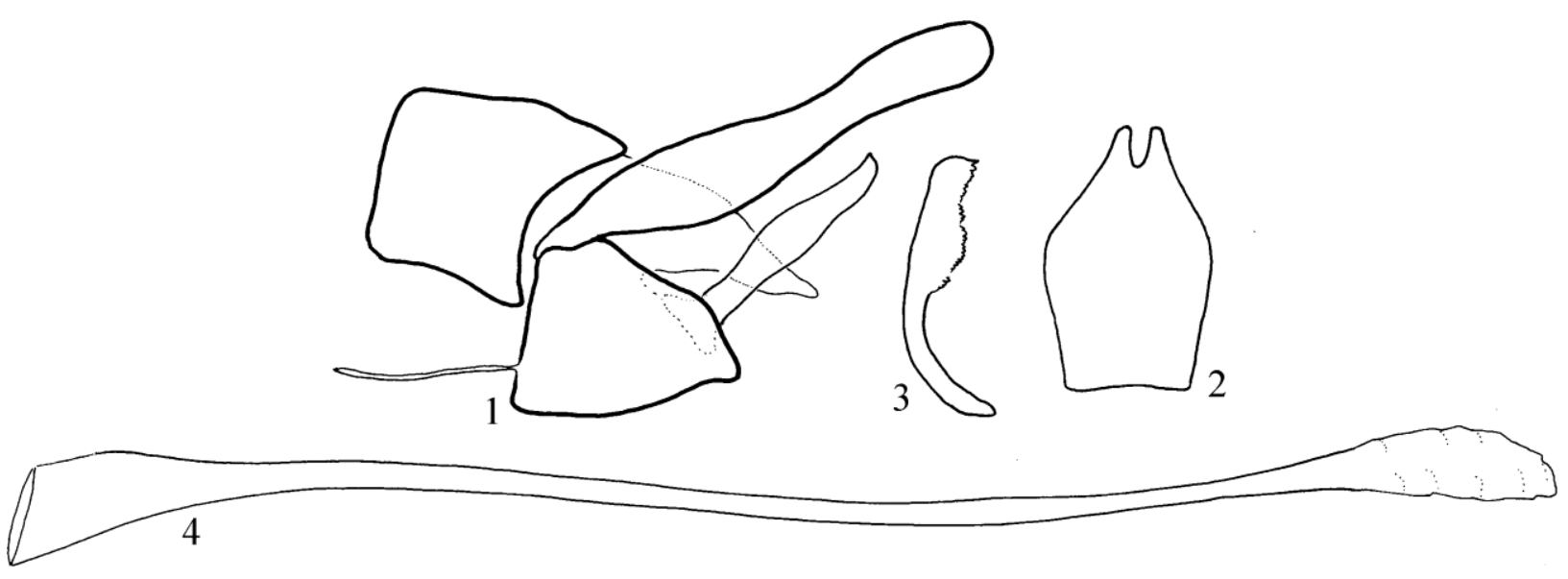

Figures 1-4. Abaria dufforum sp. nov. 1 = male genitalia in left lateral view, $2=$ tergite VIII in dorsal view, $3=$ left gonopod in ventral view, 4 = phallic organ in lateral view.

Male genitalia. Abdominal segment IX represented by subtriangular sternite and by some remnant cavity structure of tergite withdrawn under the apical margin of tergite VIII; sternite IX in lateral view as long as high, subtriangular and convex on dorsum; its long and very thin apodeme horizontal; tergite IX rudimentary, almost indiscernible as modified into cavity wall at the base of segment $X$ and retracted under tergite VIII. Tergite VIII more pigmented, its contour is well-defined and well-visible; its dorsoapical margin deeply excised; pleurotergal groove well developed. Segment X roof-shaped with tapering ventroapical end in lateral view. Cerci are elongated digitiform with well-developed constriction after middle; basal half bellied. Gonopods strongly pigmented, its coxopodite and harpago fused without any visible suture; almost straight in lateral view; laterad curving in ventral view; mesal spiny surface of gonopod with evenly sized teeth, slightly S-forming dentate along apical half of the gonopod. Phallic organ long and thin, with broad basal part and simple dilating apex, no any special structure discernible.

Material examined. Holotype. India, Kerala State, Palamattom, Birds Lagoon Village Resort, $10^{\circ} 06^{\prime} \mathrm{N}, 76^{\circ} 42^{\prime} \mathrm{E}, 30$. XI- 1. XII.2010, light leg. A. G. Duff (1 male, OPC). Paratype. Same as of holotype (1 male, OPC).
Etymology. It is with great pleasure that I name this species for Andrew G. Duff who has collected the type specimens.

\section{Family Polycentropodidae}

\section{Cyrnellus kesken sp. nov.}

(Figures 5-9)

Diagnosis. It seems that the so called widely distributed and highly varying Cyrnellus fraternus is rather a species complex. Cyrnellus kesken sp. nov. is a member of this species complex, and most close to $C$. zapateriensis Chamorro-Lacayo described from Nicaragua, but differs by anterior ventrum elongation on sternite IX short, not long reversed L-shaped; ventroapical process on the dorsal complex sclerotized, not membranous; produced laterad in dorsal view, not posterad; cerci exceeding complex, not shorter; ventral digitate process on cercus very slender compared to the ventral branch of the paraproct. Phallobase twice as broad as middle portion, not similar; phallotremal sclerite with adhered apical lobes in dorsal view, not diverted laterad.

Description. Male (in alcohol). Forewing length $4 \mathrm{~mm}$. Brown coloured animal. Second segment on maxillary palp almost as long as the third segment resulted from its mesal elongation due to the subapical lateral articulation of the third 


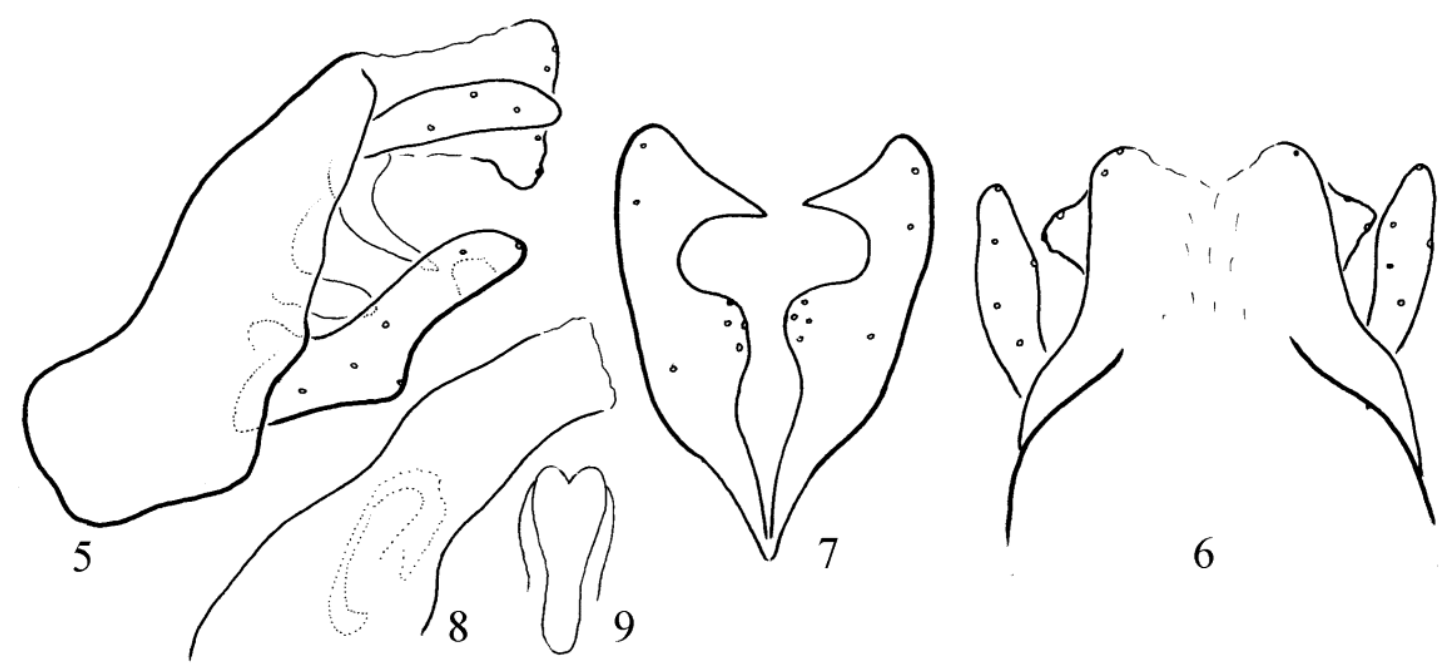

Figures 5-9. Cyrnellus kesken sp. nov. $5=$ male genitalia in left lateral view, $6=$ male genitalia in dorsal view, $7=$ gonopods in ventral view, $8=$ phallic organ in lateral view, $9=$ phallotremal sclerite in dorsal view.

segment; maxillary palp formula is I-II-IV-III-V. Forewing with closed discoidal cell, open median cell and apical forks 2,3,4,5 present. Hindwing with open discoidal cell and apical forks 2, 5 present.

Male genitalia. Sternum IX with short anteriorly elongated ventrum. Tergite IX and segment $\mathrm{X}$ membranous forming a fused complex with the paraproct; components of the fused complex difficult to homologise. Cerci slender foliform exceeding the fused complex apicad. The pair of digitate ventral process on cercus more slender in lateral view than the ventral part of the paraproct (subgennital plate). Gonopods angulate in lateral view, apicomesal lobe long triangular and pointed; the sinus between the apicomesal and middle lobes low (narrow). Phallic organ with broad basal part, phallotremal sclerite complex bilobed apicad in dorsal view, lobes adhered.

Material examined. Holotype. Argentina, Corrientes Province, Carlos Pellegrini Posada, Aguape, $28^{\circ} 32^{\prime} 26^{\prime \prime} \mathrm{S}, 57^{\circ} 10^{\prime} 20^{\prime \prime} \mathrm{W}, 24$. XI.2011, at UV light/watertrap, leg. A. G. Duff (1 male, OPC).

Etymology. Kesken from "keskeny" narrow, in Hungarian, refers to narrow and not wide bilobed apical divergence on the phallotremal sclerite in dorsal view compared to its close relatives.

\section{Cyrnellus kozepes sp. nov.}

(Figures 10-14)

Diagnosis. According to the bifid shape and position of the apicomesal lobe C. kozepes sp. nov. is related to $C$. ulmeri Flint and $C$. arotron Flint. C. arotron is immediately recognised by the large, dark sclerite complex in the aedeagus. The phallotremal sclerite complex is much less developed at $C$. ulmeri and $C$. kozepes sp. nov. However the lateral shape of this sclerite complex is different, the dorsal shape is not drawn at $C$. ulmeri. The new species differs from both relatives by having dorsal complex with apicoventral lobes present and well developed, lacking at relatives; the bifid apicomesal lobe on gonopods shifted to middle position, located middle, not subapicad; the points of bifid lobe is less developed, compared to C. ulmeri.

Description. Male (in alcohol). Forewing length $3.5 \mathrm{~mm}$. Brown coloured animal. Second segment on maxillary palp almost as long as the third segment resulted from its mesal elongation 


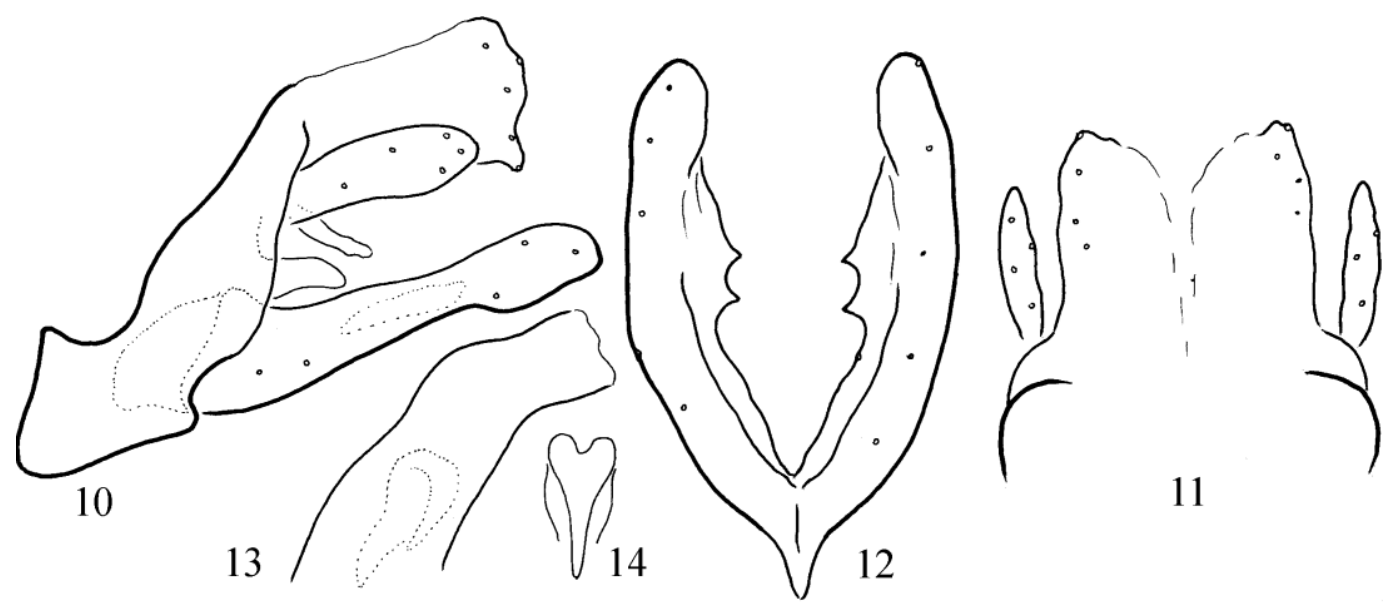

Figures 10-14. Cyrnellus kozepes sp. nov. $10=$ male genitalia in left lateral view, $11=$ male genitalia in dorsal view 12 = gonopods in ventral view, 13 = phallic organ in lateral view, $14=$ phallotremal sclerite in dorsal view.

due to the subapical lateral articulation of the third segment; maxillary palp formula is I-II-IV-III-V. Forewing with closed discoidal cell, open median cell and apical forks 2,3,4,5 present. Hindwing with open discoidal cell and apical forks 2, 5 present.

Male genitalia. Sternum IX with short anteriorly elongated ventrum. Tergite IX and segment $\mathrm{X}$ membranous forming a fused complex with the paraproct; components of the fused complex difficult to homologise. Cerci broad foliform shorter than the fused complex. The pair of digitate ventral process on cercus more slender in lateral view than the ventral part of the paraproct (subgennital plate). Gonopods angulate subapicad in lateral view, bifid apicomesal lobe located in middle position. Phallic organ with broad basal part, phallotremal sclerite complex bilobed apicad in dorsal view; lobes not much diverted laterad.

Material examined. Holotype. Argentina, Corrientes Province, Carlos Pellegrini Posada, A-

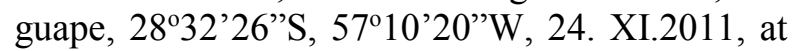
UV light/watertrap, leg. A. G. Duff (1 male, $\mathrm{OPC})$.

Etymology. Kozepes from "közepes" having middle position, in Hungarian, refers to location of the apicomesal lobe on the gonopods, shifted from subapicad ti middle.

\section{Family Hydropsychidae}

\section{Centromacronema auripenne Rambour 1842}

Material examined. Colombia, Yellow-eared Parrot Bird Reserve, village Ventanas, Jardin, Antioquia, 5०32'45.76"N, 7547'19.96”W, 6. II. 2014, caught by hand, leg. A. G. Duff (1 male, OPC).

\section{Smicridea discalis Flint, 1972}

Material examined. Argentina, Corrientes Province, Ituzaingo, Howard Johnson Express Inn, $27^{\circ} 35^{\prime} 38^{\prime \prime}$ 'S, 56 $48^{\prime} 12^{\prime \prime} \mathrm{W}, 25$. XI.2011, at lighted windows, leg. A. G. Duff (1male, OPC).

\section{Cheumatopsyche nubila Kimmins, 1963}

Material examined. Ethiopia, Awash National Park, Awash Falls Lodge, 8 ${ }^{\circ} 50^{\prime} 33.60^{\prime} \mathrm{N}, 40^{\circ} 00^{\prime}$ 45.08”E, 946 m, 28. III.2014, at light leg. A. G. Duff (10 males, 28 females; OPC).

\section{Family Hydrobiosidae}

\section{Apsilochorema annandalei Martynov, 1935}

Material examined. India, Arunachal Pradesh, Eaglenest Wildlife Sanctuary, Bomphu Camp, $27^{\circ}$ 
03'57.40'N, 92'24'21.39'E, 15. IV.2013, at light leg. A. G. Duff (1 male, OPC).

\section{Family Glossosomatidae}

\section{Glossosoma kissottoi Malicky, 1997}

Material examined. Bhutan, Bumthang Dist. Jakar, hotel, 27³2'28.41'N 9045'08.52”'E, 22. IV.2013, light leg. A. G. Duff (2 males, OPC).

\section{Glossosoma malayanum Banks, 1934}

Material examined. Bhutan, Bumthang Dist. Jakar, hotel, 2732'28.41'N, 9045'08.52”E, 22. IV.2013, light leg. A. G. Duff (1 male, OPC).

\section{Family Hydroptilidae}

\section{Orthotrichia palama sp. nov.}

(Figures 15-16)

Diagnosis. This is a species with less asymmetric genitalia having some resemblance to $O$. menjonkok Wells \& Malicky described from Indonesia (Sumatra), but differs by elongated segment $\mathrm{X}$ and lacking the spine-like free suspending discernible paraproct.

Description. Male (in alcohol). Forewing length $1 \mathrm{~mm}$. Antennae 27 segmented, scapus double long, pedicel shorter than flagellar segments; flagellar segments quadratic; maxillary palp formula I-II-IV-III-V, first two segments extremely short, shorter than wide; post occipital setal warts prominent, ovoid, not modified as scent organ. Tentorium indiscernible, only anterior arm present. Ocelli lacking. Metascutellum short rectangular. Spur formula 034. Sternum VI with very small pointed apicomesal process and sternum VII without any process.

Male genitalia. Segment IX less asymmetric, dorsum little slonger than ventrum. Segment X (dorsal plate) present as a long less-pigmented lobe with slightly asymmetric apex. Paraproct not discernible. Gonopods fused quadratic with mesal constriction. The basal plate of the gonopods vestigial with long digitiform apodeme. Phallic organ forms a long tube with broader basal half and long titillator having complex multiple turning, apex dilated bifid.

Material examined. Holotype. India, Kerala State, Palamattom, Birds Lagoon Village Resort, $10^{\circ} 06^{\prime} \mathrm{N}, 7^{\circ} 42^{\prime} \mathrm{E}, 30$. XI- 1. XII.2010, light leg. A. G. Duff (1 male, OPC). Paratype. Same as of holotype (7 males, OPC).

Etymology. Coined from the name of locus typicus.

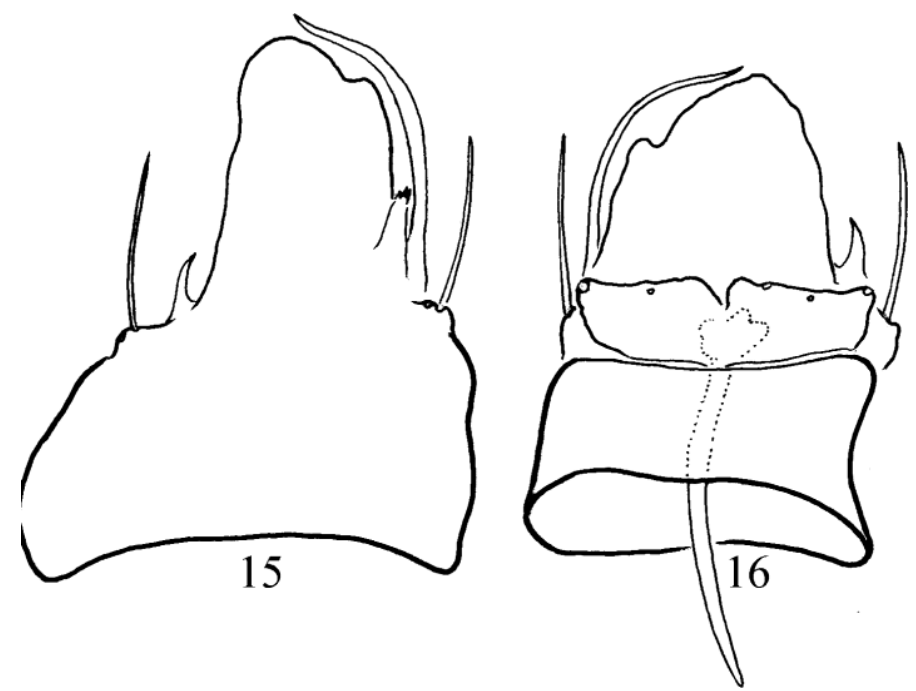

Figures 15-16. Orthotrichia palama sp. nov. $15=$ male genitalia in left lateral view, $16=$ male genitalia in dorsal view. 


\section{Family Odontoceridae}

\section{Marilia annae sp. nov.}

(Figures 17-20)

Diagnosis. This new species is most close to M. misionensis Flint described from Argentina (Misiones), but differs by having suture pattern on segment IX differently developed, pleurotergal suture vestigial, not complete; cerci slender both in dorsal and lateral view, not broad; apex of segment $\mathrm{X}$ with more produced rounded triangular; phallotheca parallel-sided in lateral view, its curvature low.

Description. Male (in alcohol). Slender, dark brownish animal. Wing membrane brown without any pattern, forewing length $11 \mathrm{~mm}$. Eyes of male virtually touching middorsally. Spur formula 244, maxillary palp formula I-V-IV-II-II.

Male genitalia. Segment IX with S-shaped anteriorly, pleurotergal suture vestigial; pleurosternal suture straghtly directed to a midapical triangular lobe. Cerci slender tapering both basad and apicad in lateral view. Segment X with blunt apicolateral triangular lobe in dorsal view. Gonopods almost parallel-sided, harpago long, slightly mesad curving. Phallotheca or aedeagus less curved, phallotremal sclerite not distinct.

Material examined. Holotype. Argentina, Corrientes Province, Carlos Pellegrini Posada, Agua-

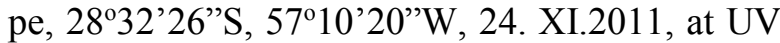
light/watertrap, leg. A. G. Duff (1 male, OPC). Paratypes. same as of holotype (2 male, 2 females, OPC)

Etymology. This beautiful dark brown and slender species with extremely enlarged male eyes is dedicated to the wife of the collector, who has accompanied her husband during his birdwatching trips.

Remarks. Marilia is a widespread genus, known from Oriental, Australasian, Nearctic and Neotropical regions. The male has variously enlarged eyes, and high degree of setal reduction on segments IX and X. Male genitalia rather similar, difficult to differentiate among species. Brace pattern of sutures on segment IX seems species specific in the Neotropical, but not so diverse in Oriental species. Marilia genus has significant enlargement of the compound eyes resulting specific modification of cephalic setal wart pattern. A long basal brush originates from the marginal surface of the small anal costal lobe near the very base of the hindwing. The setae in the brush are set close together, having the same length and form a pencil-like long brush. This pencil-like basal brush present in male absent in female and may serve some androconial function. $M$ annae sp. $\mathrm{n}$. has extremely enlarged eyes, well developed suture pattern on segment IX and complete spur pattern of 244 .

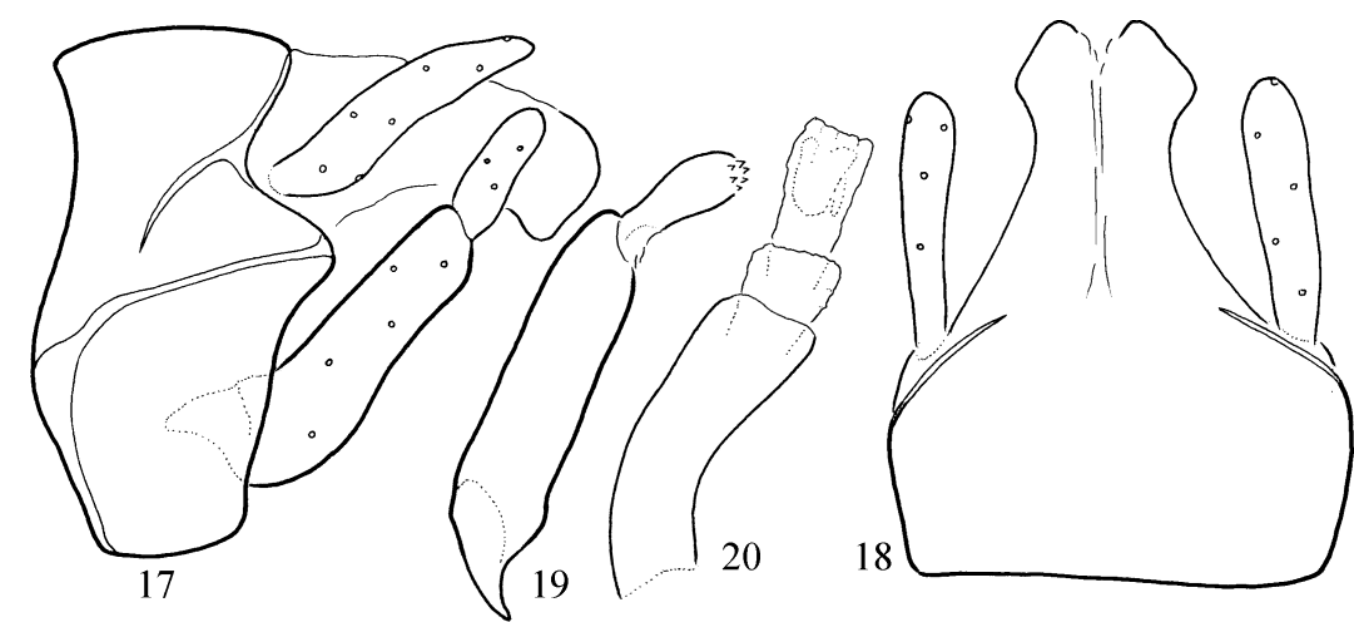

Figures 17-20. Marilia annae sp. nov. 17 = male genitalia in left lateral view, $18=$ male genitalia in dorsal view, $19=$ left gonopod in ventral view, $20=$ phallic organ in lateral view. 


\section{Family Calamoceratidae}

Phylloicus kinovos sp. nov.

(Figures 21-24)

Diagnosis. In alcohol this unicoloured dark brown species is rather similar to Phylloicus magnus Banks from Colombia, but differs by having long triangular basodorsal process, long basolateral processes and an additional short lateral process on segment $\mathrm{X}$; the phallobase has different curvature.

Description. Male (in alcohol). Dark brownish animal. Wing membrane dark brown without any pattern, densely packed with fine setae. Forewing length $18 \mathrm{~mm}$. Maxillary palp formula I-IV-V-IIIII. Tibial spur 244.

Male genitalia. Segment IX almost annular with horizontal suture at cerci. Segment X slightly sagitatte basally; basodorsal process long trian- gular, with produced apex in lateral view; basolateral processes of varying length and with some asymmetry; additional short lateral outgrowth near basolateral processes; apex truncate in lateral view, bilobed in dorsal view. Cerci digitate, shorter than segment X. Gonopods stout, coxopodite broadest midway, harpago parallel-sided. Phallic organ simple comprised of a tubular regularly arching phallobase and a membranous endotheca, phallotremal sclerite indistinct.

Material examined. Holotype. Colombia, Dusky Starfrontlet Bird Reserve, Cordillera Occidental, Urrao, Antioquia, 6 $26^{\prime} 10.8^{\prime \prime} \mathrm{N}, 76^{\circ} 5^{\prime}$ 25.15" W, 8. II. 2014, caught by hand, leg. A. G. Duff (1 male, OPC). Paratypes. Same as of holotype (2 males, OPC).

Etymology. Kinovos from "kinövős" with produced outgrowths", in Hungarian, refers to the produced digitate processes on segment $\mathrm{X}$, compared to its sibling Phylloicus magnus.

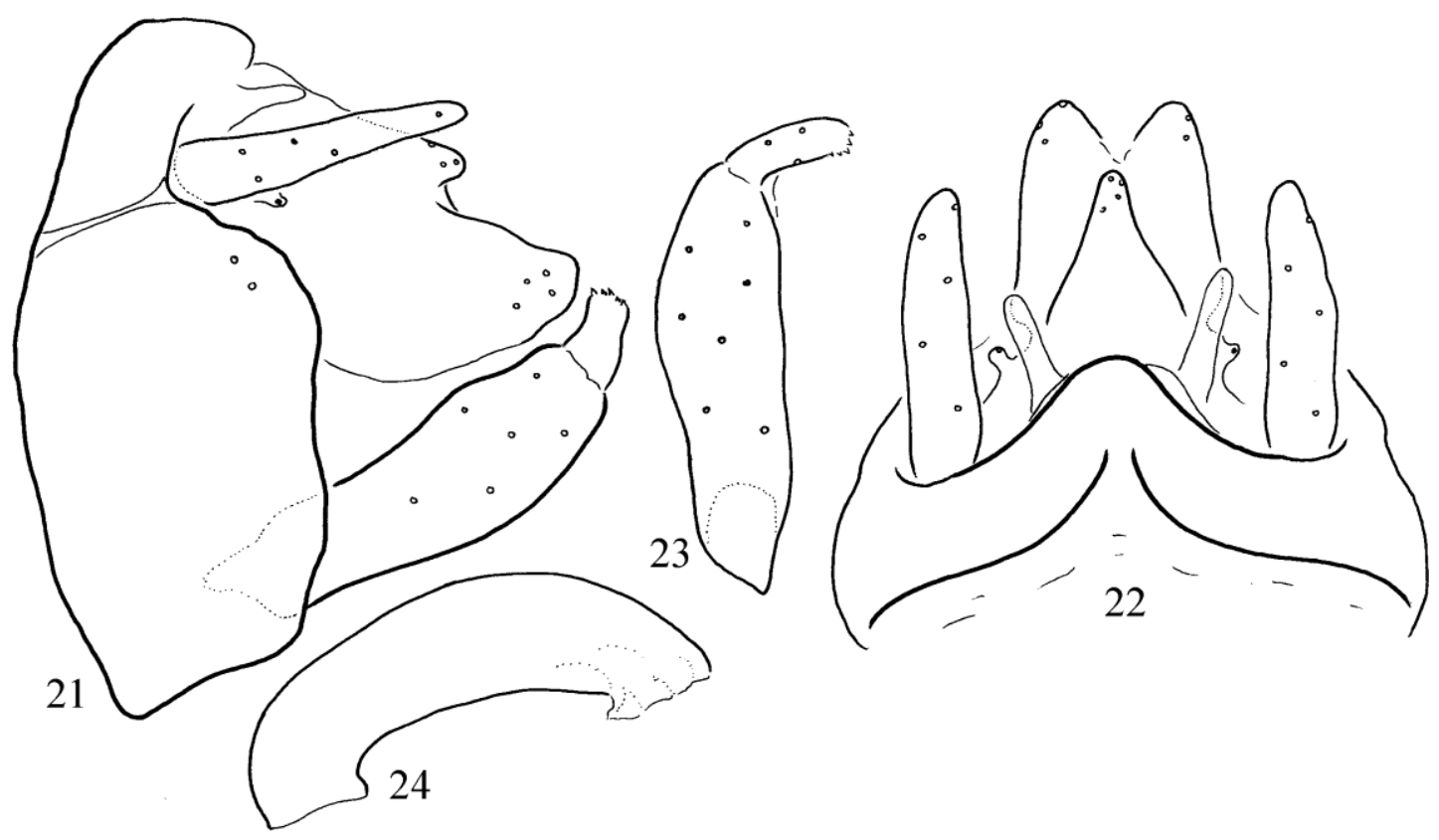

Figures 21-24. Phylloicus kinovos sp. nov. $21=$ male genitalia in left lateral view, $22=$ male genitalia in dorsal view, 23 = left gonopod in ventral view, 24 = phallic organ in lateral view. 


\section{Family Leptoceridae \\ Subfamily Triclectidinae}

\section{Atanatolica homora sp. nov.}

(Figures 25-28)

Diagnosis. This very slender animal is dark brown in alcohol. Distinguished from all the known species by its nominate character, the concave lateral profile of lower terminal region of the gonopods as well as by the presence of an additional less sclerotized pair of broad basolateral processes on segment X.

Description. Male (in alcohol). Dark brownish animal. Wing membrane dark brown without any pattern, densely packed with fine setae. Forewing length $11 \mathrm{~mm}$. Maxillary palp formula I-IV-V-IIIII.

Male genitalia. Segment IX almost annular with horizontal suture at cerci. Segment $X$ rather complex, composed of apicomesal pair of most upward directed processes capitate in dorsal view, more tapering apicolateral pair of processes and an additional less sclerotized pair of broad basolateral lobes densely packed with short peglike setae. Cerci digitate, shorter than segment X. Gonopods stout with shorter, higher (broader) basal region and longer, lower (narrower) apical region; small vestigial harpago present at the border between the basal and apical regions; apical region with highly concave lateral profile. Phallic organ simple, comprised of a tubular less arching phallobase and phallotheca and a membranous endotheca; phallotremal sclerite well sclerotized composed of dorsal and ventral parts, dorsal view of the dorsal sclerite bilobed.

Material examined. Holotype. Peru, Norther Peru, Abra Patricia Conservation Area, Amazo-

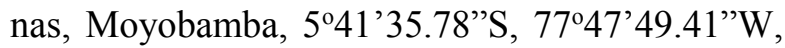
10. IX. 2014, at light, leg. A. G. Duff (1 male, OPC).

Etymology. Homora from "homorú" concave, in Hungarian, refers to the concave laterale profile of the low terminal segment of the gonopods..

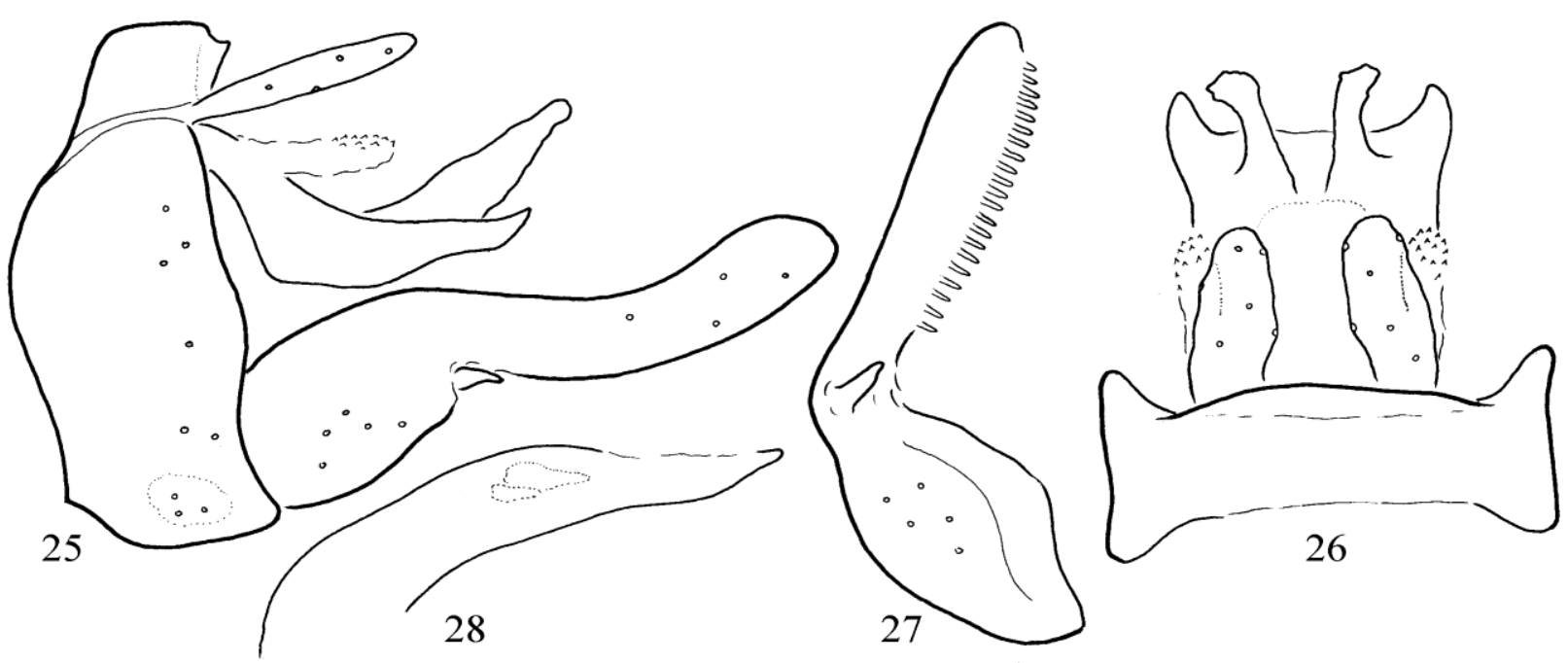

Figures 25-28. Atanatolica homora sp. nov. $25=$ male genitalia in left lateral view, $26=$ male genitalia in dorsal view, $27=$ left gonopod in ventral view, $28=$ phallic organ in lateral view. 


\section{Subfamily Leptocerinae}

\section{Nectopsyche Müller, 1879}

According to Holzenthal (1995) the species of the Nectopsyche genus are among the most beautifully coloured Trichoptera. Their forewing patterns are striking in appearance due to the presence of coloured hairs and scales with metallic or iridescent character. Specimens stored in alcohol usually very much denuded, forewing pattern and colour are usually lost. Identity of species is based largely on coloration pattern and less on male genital structure. However pinned, unrubbed specimens collected in dry, clean, cyanide killing jars, handled very carefully and mounted on pins, are seldom available for biodiversity studies. Moreover differences both in colour pattern and in genital structure are often subtle, but experienced apparently stable, even in sympatry with some intraspecific variation, but with very little interspecific overlap (Holzethal, 1995). A parallel careful examination and colourful illustration of forewing pattern on pinned material and very careful examination and detailed illustrations of the male genitalia are essential to a proper revision of this genus
(Holzethal, 2016, personal communication).

Nectopsyche bruchi (Navas, 1920)

Material examined. Argentina, Corrientes Province, Carlos Pellegrini Posada, Aguape, 28 $8^{\circ} 2^{\prime}$ 26”S, 57¹0'20”W, 24. XI.2011, at UV light/ watertrap, leg. A. G. Duff (1 male, OPC).

\section{Nectopsyche padrenavasi Holzenthal, 1999}

(Figures 29-38)

Material examined. Argentina, Corrientes Province, Ituzaingo, Howard Johnson Express Inn, 27'35'38”S 56 $48^{\prime} ' 12^{\prime \prime} \mathrm{W}, 25$. XI.2011, at lighted windows, leg. A. G. Duff (2 males, 15 females; $\mathrm{OPC})$.

Remarks. Specimens of Nectopsyche padrenavasi collected in alcohol by A. G. Duff were completely denuded. My genital drawings do not match to any published genital drawings. I have sent my diagrammatic genital drawings for determination to Professor Ralph Holzenthal who have drawn, but not published yet the genital structure of this poorly known species.

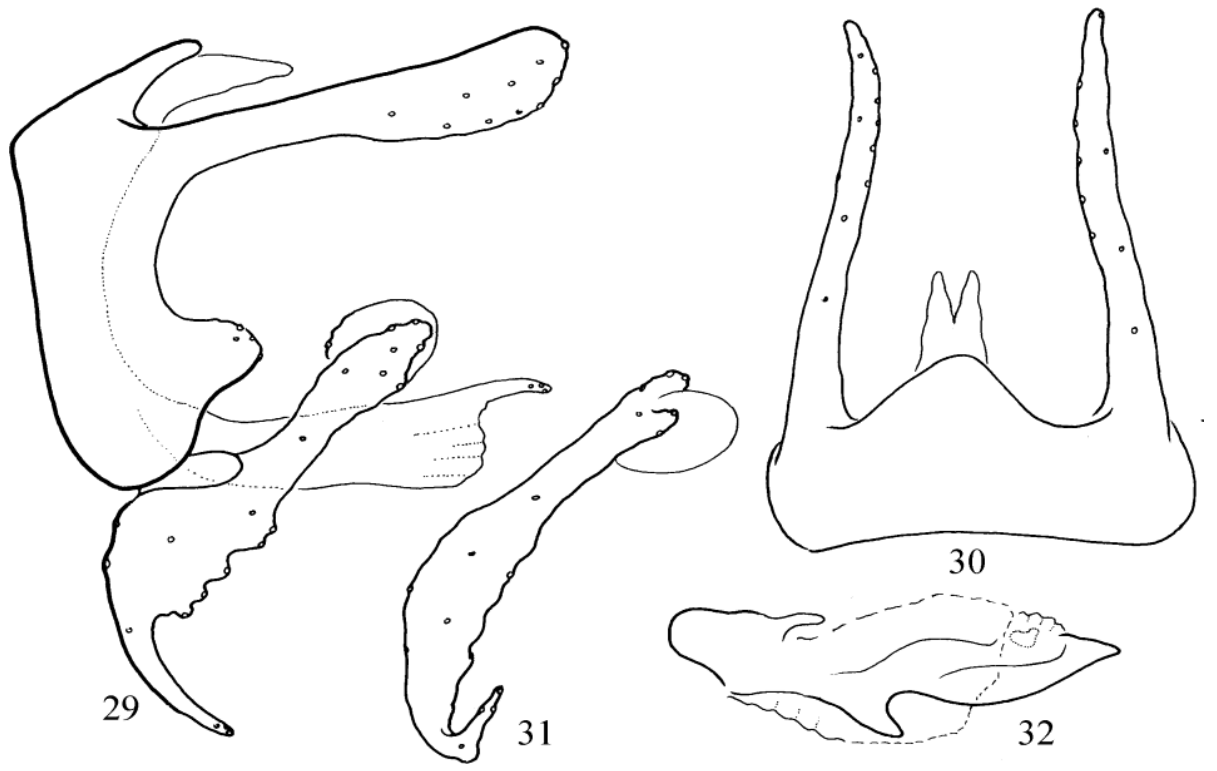

Figures 29-32. Nectopsyche padrenavasi Holzenthal, 1999. 29 = male genitalia in left lateral view, $30=$ male genitalia in dorsal view, 31 = left gonopod in ventral view, $32=$ phallic organ in lateral view. 


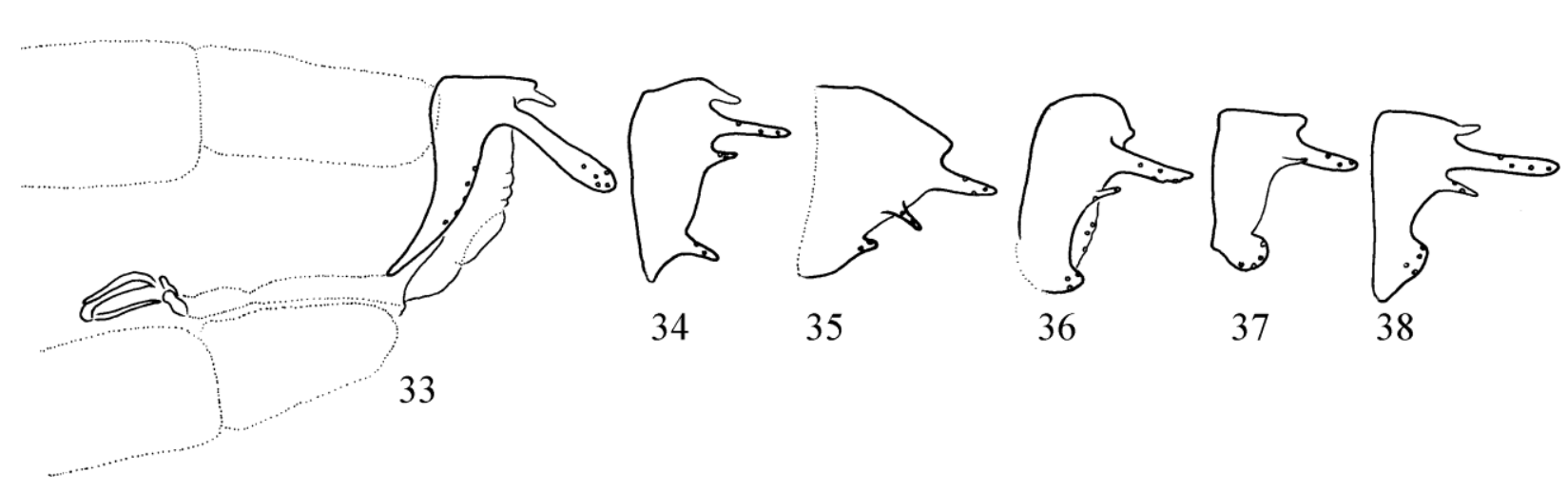

Figures 33-38. Female genitalia of Nectopsyche padrenavasi Holzenthal, 1999 compared to other species. $33=$ female genitalia in left lateral view, $34=$ female segment IX of $N$. cubana in lateral view, $35=$ female segment IX of $N$. exquisita in lateral view, $36=$ female segment IX of $N$. gemmoides in lateral view, $37=$ female segment IX of $N$. lewisi in lateral view, $38=$ female segment IX of $N$. paludicola in lateral view,

\section{Nectopsyche sp.}

Material examined. Holotype. Colombia, Dusky Starfrontlet Bird Reserve, Cordillera Occidental, Urrao, Antioquia, 6 $6^{\circ} 26^{\prime} 10.8^{\prime \prime} \mathrm{N}, 76^{\circ} 5^{\prime}$ 25.15”W, 8. II. 2014, caught by hand, leg. A. G. Duff (1 male, OPC).

Remarks. Upon personal request this new species is set aside to describe until Ralph Holzenthal will complete his revision both on genital fine structure and forewing pattern of this very diverse genus with plenty of species complexes of closely related siblings.

\section{Oecetis amazonica species complex}

Material examined. Argentina, Corrientes Province, Ituzaingo, Howard Johnson Express Inn, $27^{\circ} 35^{\prime} 38^{\prime}$ S, 56 48'12”W, 25. XI.2011, at lighted windows, leg. A. G. Duff (1 male, OPC). Argentina, Corrientes Province, Carlos Pellegrini Posa-

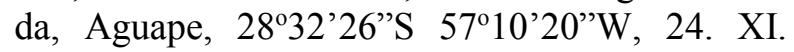
2011, at UV light/watertrap, leg. A. G. Duff (4 males, 2 females; OPC).

Remarks. Specimens from the two localities represent two undescribed species and a new species complex (see theoretical part). Based on the principles of fine structure analysis of the phallic organ we can delineate these young species also in this species complex. However, more comparative material is required to describe our species collected in Argentina.

\section{Oecetis fura sp. nov.}

(Figures 39-40)

Diagnosis. The fused ventrum and pleuron form the basic body of segment IX; the dorsum of segment IX is reduced to a short band receiving the vestigial body of segment $\mathrm{X}$, the fused long mesal lobe of segment $X$ and the cerci. The fused ventrum and pleuron is uniquely subdivided into a pair of dorsal lobe and the rest ventrum. Such a structural development in the Oecetis genus is present only in a single known species, $O$. dakchineswara Schmid, 1995 described from Mysore of Karnataka State, India. The new species differs only in small divergences in the shape of the dorsal lobe of segment IX and of the gonopods as well as the apex of the mesal lobe of segment X has been modified.

Description. Male (in alcohol). Pale, yellowish animal. Wing membrane pale without any pattern, except crossveins have some brown pigmented small patches; forewing length $8 \mathrm{~mm}$.

Male genitalia. Segment IX subdivided, dorsum reduced to a short band, fused ventrum and pleuron split into a pair of dorsal lobe and basal body of the segment. Segment X consisting of a slender median process, with pointed apex, accompanied by some subapical small out- 


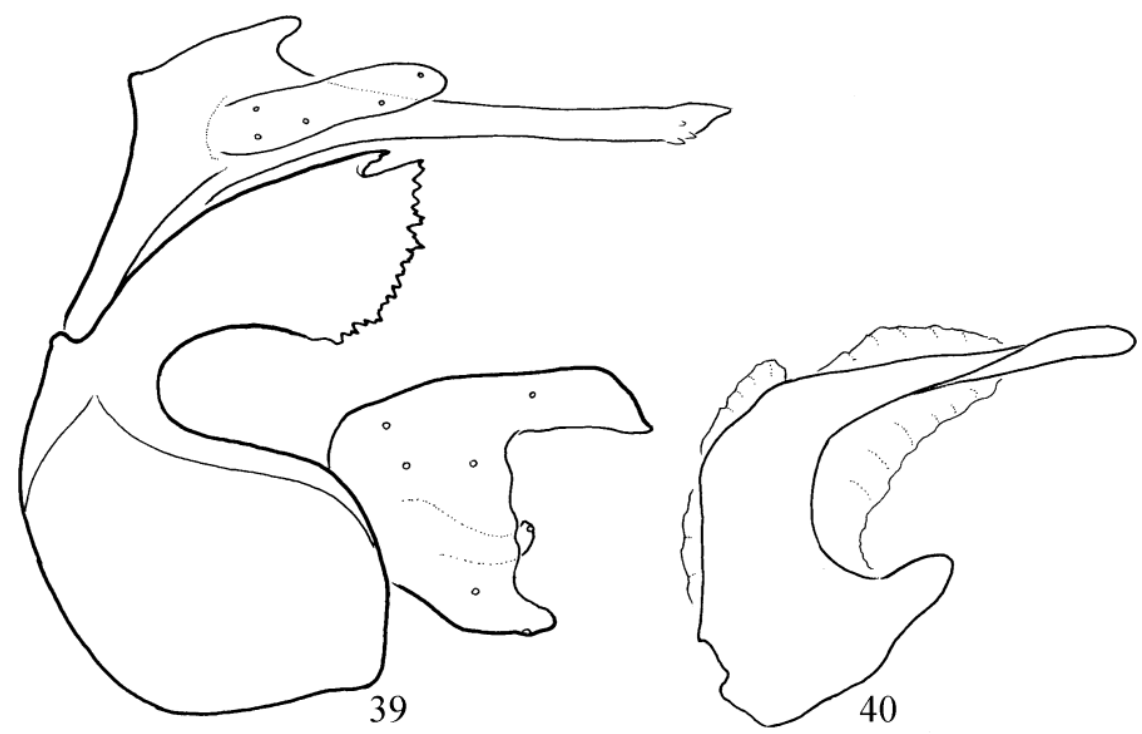

Figures 39-40. Oecetis fura sp. nov. $39=$ male genitalia in left lateral view, $40=$ phallic organ in lateral view.

growths. Cerci elongated foliate. Gonopods falcate in lateral view with a mesal additional lobe. Phallic organ asymmetrical with left-side sclerotized elongated and downward directed phallotheca, accompanied by a large membranous right side disposed membranous endotheca.

Material examined. Holotype. India, Kerala State, Palamattom, Birds Lagoon Village Resort, $10^{\circ} 06^{\prime} \mathrm{N}, 76^{\circ} 42^{\prime} \mathrm{E}, 30$. XI-1. XII.2010, light leg. A. G. Duff (1 male, OPC).

Etymology. Fura from "fura" unusual, in Hungarian, refers to the unusually subdivided ventrum of segment IX.

\section{Oecetis inconspicua complex}

This known species complex, populating North and South America, may prove to contain significant species diversity still waiting to be described (Blahnik \& Holzenthal, 2014). Larval morphology and cytochrome c oxidase subunit I (COI) sequences demonstrated that the examined populations of Oecetis inconspicua (Walker, 1852) represent a large species complex and need detailed revision. Studies on a limited number of populations revealed seven larval types (Floyd 1995) and 21 divergent COI clusters (Zhou et al. 1995). However, as usual, the real taxonomic re- vision is awaited to be realised with adult phenolmics of speciation traits. Those are the most diverged and stable genital structures or fine structures, the reproductive barrier products of sexual selection which are integrated under nonneutral, adaptive processes.

We have a few specimens from this complex collected in Argentina, outside of the presently known distribution range. We describe this population as a new species to give some impetus to a detailed revision. Our species delimitation is based primarily on the shape of the phallobase in lateral view. The intromittent organs have proved to be the most divergent and stable speciation traits in the caddisfly families of Hydropsychidae (Oláh \& Johanson 2008a, b, 2012, Oláh \& Kiss 2015), Hydroptilidae (Oláh \& Ito 2013) and Limnephilidae (Oláh et al. 2015). The shape of the phallobase was found as the single most useful character also in the Oecetis avara group (Blahnik \& Holzenthal 2014).

\section{Oecetis siska sp. nov.}

(Figures 41-46)

Diagnosis. If we compare the periphallic organs with all the published drawings, O. siska sp. nov. is most close to drawings of the popula- 

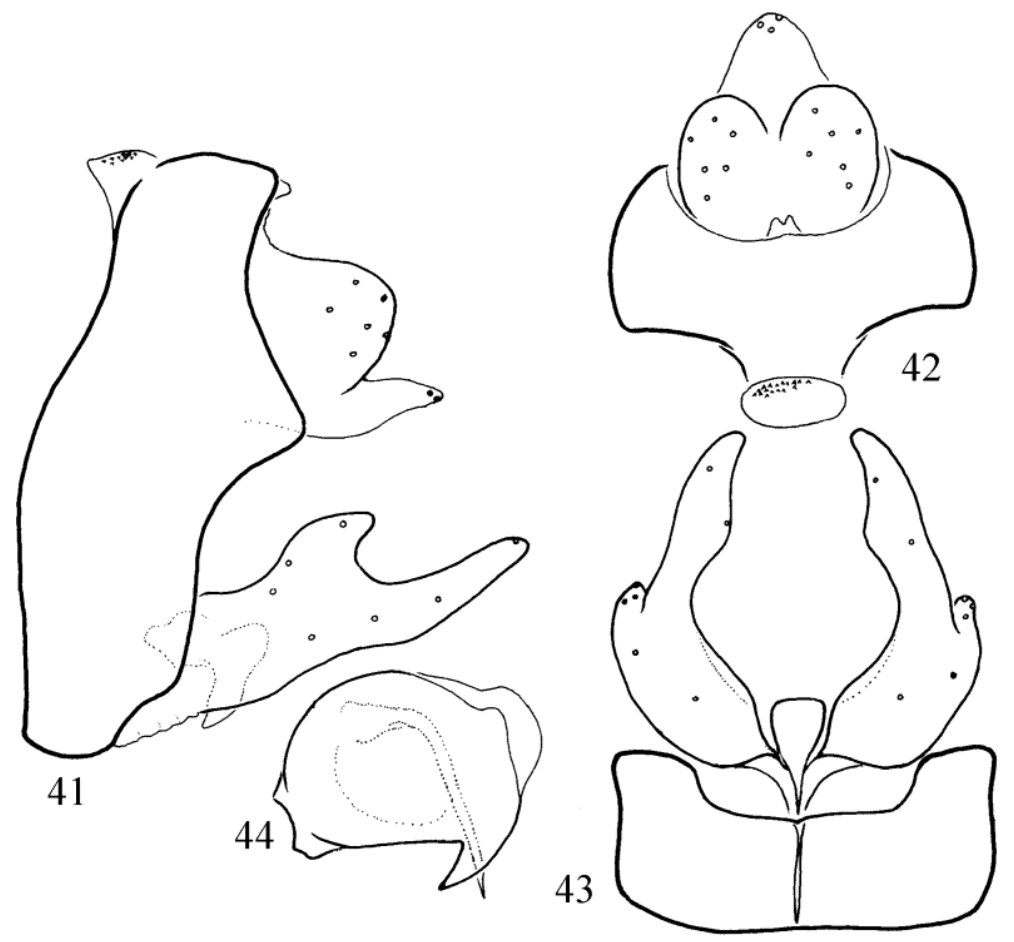

Figures 41-44. Oecetis siska sp. nov. 41 = male genitalia in left lateral view, $42=$ male genitalia in dorsal view 43 = male genitalia in ventral view, 44 = phallic organ in lateral view.

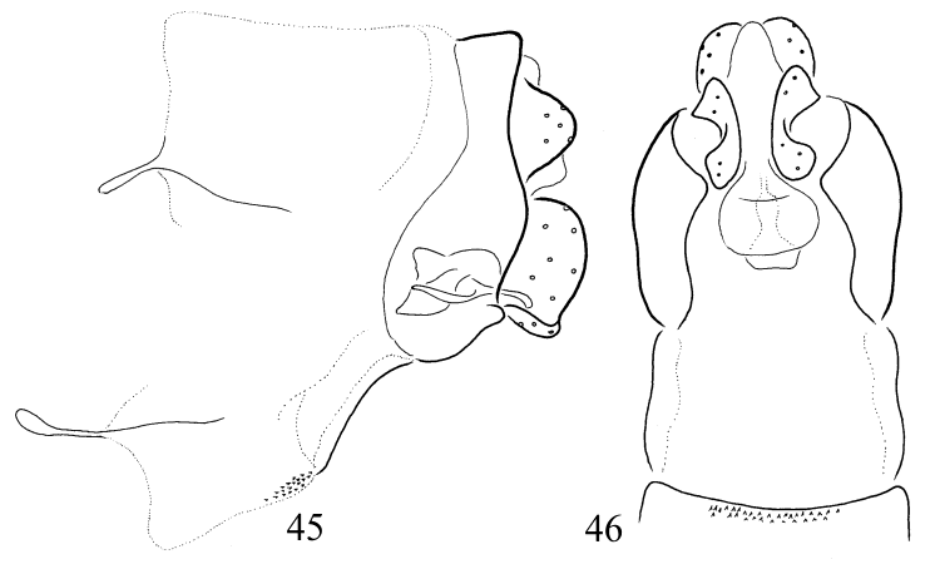

Figures 45-46. Oecetis siska sp. nov. 45 = female genitalia in left lateral view, 46 = female genitalia in ventral view.

tion from SE Brazil (Quinteiro \& Calor, 2015), but the tip of segment $\mathrm{X}$ is triangular, not bilobed; the dorsal arm of the gonopod slender, not blunt; anteromesal region of dorsum IX produced, not concave; antecosta is discontinuous at acrotergite, not continuous; and moreover the membranous fulcrum excision on the apicomesal region of ventrum IX is very wide, not narrow. The lateral profile of the ventrum of the phallobase forms a uniquely long straight line, not short and not arched or bent. This trait is very stable at all the specimens, as examined at high resolution and at free disposition.

Description. Male (in alcohol). Pale brown animal. Male forewing length $8 \mathrm{~mm}$, female fore- 
wing length $7 \mathrm{~mm}$. Wing membrane pale without any pattern, except around crossveins there are some brown pigmented patches; spacing of the crossveins in the anastomosis (known also as chord, the diagonal line of crossveins more or less dislocated) seems stable at the examined 4 male and 1 female specimens: crossvein $s$ placed more apicad and crossveins $r-m$ and $m$ arranged linearly placed basad.

Male genitalia. Segment IX fused, short annular, dorsum with produced anteromesal region, accompanied by a transversally ovoid acrotergite; apicomesal region of ventrum IX with a wide membranous excision giving fulcrum space for gonopod function during copulatory movement. Segment $X$ short, triangular. Cerci rounded. Gonopods with longer ventroapical and shorter dorsal arms, basal plate of gonopods visible as a more sclerotized triangulum in ventral view. Phallic organ rounded, composed of somehow asymmetrical dorsal emarginations, long straight spine with basal bent, the lateral profile of the sclerotized phallobase is straight.

Female genitalia. Abdominal segment VIII complete, does not deviate much from the preceding segments; tergite and sternite VIII with short and thin anterolateral apophysis, the continuation of the longitudinal sutures; membranous pleural region large; ventrum VIII oblique with bare granulosed rugose surface. Segment IX short, broadening ventrad, dorsoapical pair of tiny papillae present. Cerci (preanal appendages, Yang \& Morse 2000) semicircular. Sternite IX (lamellae) setose both on the lateral and mesal surfaces, double high than long, ventrum laterad directed. Segment X short, less pigmented, bare, flanked by cerci and forming the upper lip of vaginal opening. The complex gonopod of segment VIII and IX fused, glabrous, less sclerotized except the brown pigmented lateral bands. Vaginal sclerite complex well sclerotized and discernible.

Material examined. Holotype. Argentina, Corrientes Province, Carlos Pellegrini Posada, Aguape, $28^{\circ} 32^{\prime} 26^{\prime \prime} \mathrm{S}, 57^{\circ} 10^{\prime} 20^{\prime \prime} \mathrm{W}, 24$. XI.2011, at UV light/watertrap, leg. A. G. Duff (1male, OPC). Allotype. Same as of holotype (1 female, OPC). Paratypes. Same as of holotype (3 males, OPC).

Etymology. Siska from "siska" a local variety of "egyenes" straight, in Hungarian, refers to the straight ventrum of the phallobase in lateral view.

\section{Family Anomalopsychidae}

\section{Contulma duffi sp. nov.}

$$
\text { (Figures 47-49) }
$$

Diagnosis. Having long membranous segment $\mathrm{X}$ and long dorsolateral process on sternite IX most similar to Contulma bacula Holzenthal \& Flint, 1995 described from Ecuador, but differs by having tergite IX high, not low; dorsolateral process on sternite IX arching, not straight and longer than the sternite itself; both lateral and ventral shape of gonopods different.
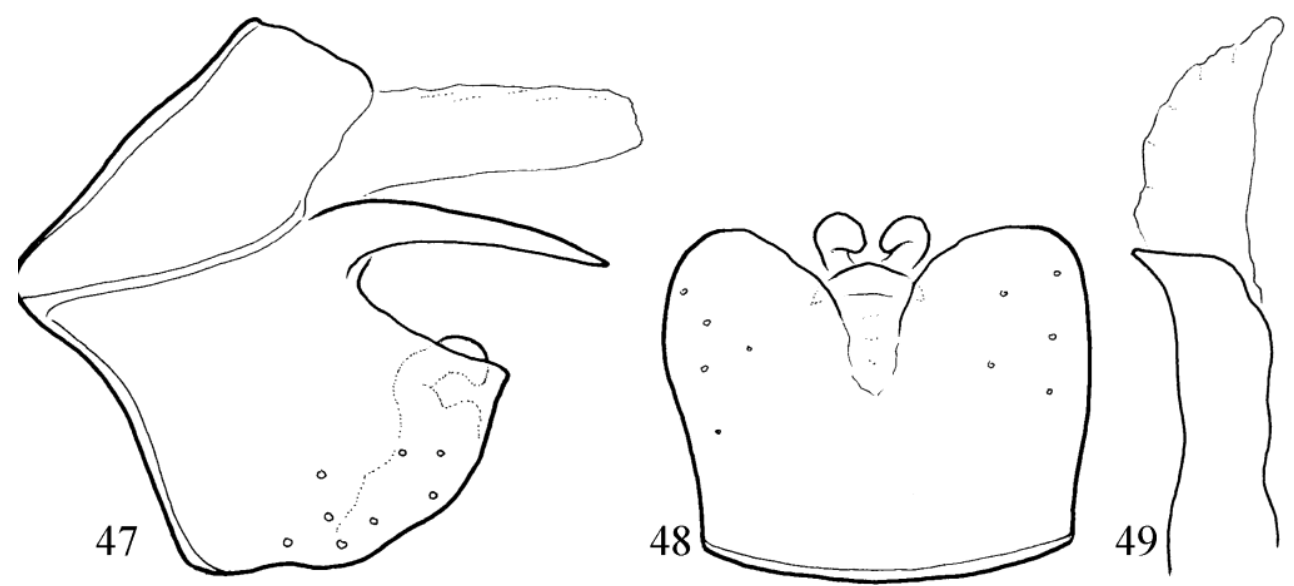

Figures 47-49. Contulma duffi sp. nov. $47=$ male genitalia in left lateral view, $48=$ male genitalia in ventral view, $49=$ phallic organ in lateral view. 
Description. Male (in alcohol). Pale, brownish animal. Wing membrane pale without any pattern, densely packed with setae. Forewing length 5 $\mathrm{mm}$. Ocelli 3. Maxillary palpi 5-segmented. Tibial spur 224, second spur of foreleg minute, no longer than wide. On forewing Rs shorter than either $\mathrm{R} 2+3$ or R4+5; MP fused, hence fork IV absent; discoidal and thyridial cells short, subequal; the crossvein from $\mathrm{M} 3+4$ joins the stem of $\mathrm{CuA}$ well basad of its fork.

Male genitalia. Posterior half of segments heavily setose, setae on tergum VIII longest. Segment IX synscleritous, triangular anterad; subdivided into tergite and sternite by a horizontal suture; sternite with a long arching and tapering dorsolateral processes. Segment X long quadratic membranous. Cerci indiscernible lost. Gonopods receded in sternite IX, falcate in lateral view; a pair of falcate process with a basal plate. Phallic organ simple, comprised of a tubular phallobase and a membranous endotheca.

Material examined. Holotype. Colombia, Dusky Starfrontlet Bird Reserve, Cordillera Occidental, Urrao, Antioquia, $6^{\circ} 25^{\prime} \mathrm{N}, 76^{\circ} 05^{\prime} \mathrm{W}, 9$. II. 2014, caught by hand, leg. A. G. Duff (1 male, OPC).

Etymology. This new species is dedicated to the collector, Andrew G. Duff who was collecting caddisflies during his birdwatching trips.

Remarks. Contulma species are characterized by rarity. Adult specimens seldom fly to light; this specimen was also collected by hand.

\section{REFERENCES}

BLAHNIK, R.J. \& Holzenthal, R.W. (2014): Review and redescription of species in the Oecetis avara group, with the description of 15 new species (Trichoptera, Leptoceridae). ZooKeys, 376: 1-83. doi: $10.3897 /$ zookeys.376.6047

FLINT, O.S. Jr. (1964): The caddisflies (Trichoptera) of Puerto Rico. University of Puerto Rico, Agricultural Experiment Station, Technical Paper No. $40,80 \mathrm{pp}$.

Flint, O.S. JR., HOlzENTHAL, R.W. \& HARRIS, S.C. (1999): Nomenclatural and systematic changes in the Neotropical caddisflies (Insecta: Trichoptera). Insecta Mundi 13(1-2): 73-84.

FLOYD, M.A. (1995): Larvae of the caddisfly genus Oecetis (Trichoptera: Leptoceridae) in North America. Bulletin of the Ohio Biological Survey, New Series, 10: 1-85.

HolzENTHAL, R.W. (1995): The caddisfly genus Nectopsyche: new gemma group species from Costa Rica and the Neotropics (Trichoptera: Leptoceridae). Journal of the North American Benthological Society 14(1):61-83. doi: $\underline{10.2307 / 1467725}$

Malicky, H. (2004): Atlas of European Trichoptera. Second Edition. Springer, Dordrecht, The Netherlands, $359 \mathrm{pp}$.

Martin, P.R., GibOn, F.-M. \& MolinA, C.I. (2011): The genus Oecetis McLachlan in Bolivia and northwestern Argentina (Trichoptera: Leptoceridae), with new species and identification key for males of Oecetis species from Mexico, Central and South America. Zootaxa, 2821: 19-38.

OLÁH, J. \& JOHANSON, K.A. (2008a): Revision of the Oriental and Afrotropical species of Cheumatopsyche Wallengren (Hydropsychidae, Trichoptera). Zootaxa, 1702: 3-171.

OLÁH, J. \& JOHANSON, K.A. (2008b): Generic review of Hydropsychinae, with description of Schmidopsyche, new genus, 3 new genus clusters, 8 new species groups, 4 new species clades, 12 new species clusters and 62 new species from the Orinetal and Afrotropical regions (Trichoptera: Hydropsychidae). Zootaxa, 1802: 3-248.

OLÁH, J. \& JOHANSON, K.A. (2012): New species and records of Neotropical Macronematinae and Smicrideinae (Trichoptera: Hydropsychidae). Annales Historico-Naturales Musei Nationalis Hungarici 104: 215-294.

OlÁH, J. \& ITO, T. (2013): Synopsis of the Oxyethira flavicornis species group with new Japanese Oxyethira species (Trichoptera, Hydroptilidae). Opuscula Zoologica, Budapest 44(1): 23-46.

Oláh, J., Chvojka, T.P., Coppa, G., Graf, W., IBRAHIMI, H., LODOVICI, O., RUIZ GARCIA, A., SÁINZ -BARIÁIN, M., VALle, M. \& ZAMORA-MuÑOZ, C. (2014): The genus Allogamus Schmid, 1955 (Trichoptera, Limnephilidae): revised by sexual selection-driven adaptive, non-neutral traits of the phallic organ. Opuscula Zoologica, Budapest, 45(1): 33-82. 
OlÁH, J., ChVoJKa, T.P., COPPA, G., GODUNKO, R.J., LODOVICI, O., MAJECKA, K., MAJECKI, J., SzCZESNY, B., URBANIC, G. \& VAlle, M. (2015): Limnephilid taxa revised by speciation traits: Rhadicoleptus, Isogamus, Melampophylax genera, Chaetopteryx rugulosa, Psilopteryx psorosa species groups, Drusus bolivari, Annitella kosciuszkii species complexes (Trichoptera, Limnephilidae). Opuscula Zoologica, Budapest, 46(1): 3-117. doi: $\underline{10.18348 / o p z o o l .2015 .1 .3}$

OLÁH, J. \& KISS, O. (2015): New species and records of Trichoptera from Turkey. Folia Historico Naturalia Musei Matraensis, 39: 99-104.

QuinTEIRO, F.B. \& CALOR, A.R. (2015): A review of the genus Oecetis (Trichoptera: Leptoceridae) in the northeastern region of Brazil with the description of 5 new species. PLoS One, 10(6): e0127357. doi: $\underline{10.1371 / \text { journal.pone. } 0127357}$

SCHMID, F. (1951): Monographie du genre Halesus (Trich.). Trabajos del Museo de Ciencias Naturales de Barcelona, Nueva Serie Zoologica, 1(3): 1-71.

Zhou, X., Robinson, J.L., Geraci, C.J., PARKer, C.R., Flint, O.S. JR., Etnier, D.A., RUiter, D., DE WALT, E., JacoBUS, L.M. \& HEBERT, P.D.N. (2011): Accelerated construction of a regional DNA-barcode reference library: caddisflies (Trichoptera) in the Great Smokey Mountains National Park. Journal of the North American Benthological Society, 30: 131-162. doi: 10.1899/10-010.1 